\title{
Anaerobic digestion of tannery solid waste by mixing with different substrates
}

\author{
S.R. Basak ${ }^{1}$, M.A. Rouf ${ }^{2}$, M.D. Hossain ${ }^{3}$, M.S. Islam ${ }^{2}$, T. Rabeya ${ }^{2}$ \\ ${ }^{I}$ Department of Civil \& Environmental Engineering, Shahjalal University of Science \& Technology (SUST), Sylhet, Bangladesh \\ ${ }^{2}$ Institute of Fuel Research and Development (IFRD), BCSIR, Dr. Qudrat-I- Khuda Road, Dhanmondi, Dhaka, Bangladesh \\ ${ }^{3}$ Department of Civil Engineering, Bangladesh University of Engineering \& Technology (BUET), Dhaka, Bangladesh
}

\begin{abstract}
The tannery solid waste (fleshing) was collected from Hazaribagh, Dhaka. It has been found that fleshing contains $82.57 \%$ volatile matter. Further characterization of fleshing showed that it contains low $\mathrm{C} / \mathrm{N}$ ratio of 2.64 and high $\mathrm{pH}$ of 10.99 . These characteristics were not suitable for using fleshing as a substrate for anaerobic digestion. The study has been carried out in different ratio of waste fleshing, domestic sewage and cow dung at total solid $6 \%$ concentration. In all the reactors fleshing and domestic sewage were mixed at 1:1 ratio. On the basis of the performance of the reactors it was evident that the reactor which contains $75 \%$ fleshing with domestic sewage and $25 \%$ cow dung showed optimum result. Under optimum condition volatile solids destruction 52\%, specific gas production $0.476 \mathrm{~L} / \mathrm{g}$ volatile solids feed and methane yield $73 \%$ were achieved.
\end{abstract}

Keywords: Anaerbic digestion; Tannery solid waste; Biogas

\section{Introduction}

Leather and leather products have always been a part of our heritage and after the emergence of independent Bangladesh in 1971 , the industry received a fresh momentum. Bangladesh started exporting crust and finished leather in early 80 's and footwear and other manufactured leather goods during 90's. The contribution of leather industrial sector in the past decade was around.

US\$ 250 million per year, accounting for around 3\% of the country's export. Leather and leather goods are the third exportable item from Bangladesh according to Export Promotion Bureau (EPB) report. The leather industrial sector of Bangladesh has been almost entirely supported by local raw material resources. Based on UNIDO consultant's detailed interaction with the Hide and Skin Merchants Association in December 2005 as well as with a number of tanners and its own assessment, the weight of raw material processed in Bangladesh annually is estimated at present at about 85,000 t/y, with about $48,000 \mathrm{t} / \mathrm{y}(\sim 56 \%)$ belonging to cows, $11,000 \mathrm{t} / \mathrm{y}$ $(\sim 13 \%)$ to buffalo and $26,000 \mathrm{t} / \mathrm{y}(\sim 31 \%)$ to goats and sheep (Nemec, 2010). Peak season of the local tanning industry is the Qurbani or sacrifice of domestic animals (typically cows and goats) during the Eid-ul-Azha festival, which takes place each year. Accordingly the peak load during the Qurbani period is estimated at $450 \mathrm{t} / \mathrm{d}$ and the load during the rest of the year $(225$ days), at about $230 \mathrm{t} / \mathrm{d}$ (Nemec, 2010). Out of the total 206 tanneries in Bangladesh 192 of them are located in Hazaribagh area of Dhaka City.
The tanning industry of Bangladesh is primarily concentrated in Hazaribagh ( 25 ha of land within Dhaka City) as most of the operating tanneries are located there (Rahman, 1984). According to UNIDO report (Nemec, 2010) 15,000 $\mathrm{m}^{3}$ of highly polluted wastewater generated everyday by tanneries in Hazaribagh area is discharged untreated into the open channel drains along the roadside passing through the area, which then eventually ends up in the Buriganga river. Often, the drains in the area spill over causing a highly unhealthy atmosphere. Leather manufacturing processes generate solid wastes varying in composition and quantity at various stages (Thangamani et. al., 2009). Hence, the solid waste management systems of Hazaribagh area require special attention to reduce environmental hazards. A major portion of the solid wastes from leather industry is fleshing which contains mainly fat and protein and residual chemicals such as lime and sulphide used in the unhairing process of beam house operation (Thangamani et. al., 2009). Anaerobic digestion of tannery waste has been studied by (Cirne et. al., 1982; Thangamani et. al., 2009; Seadi et. al., 2008; Rahaman and Muyeed, 2010; Cirne et. al., 2007; Deublein and Steinhauser, 2008; Oliveira et. al., 2004). Research work for generation of biogas from Bangladesh tannery solid waste is yet to be done although the substrate has good potential for biogas generation. The main objective of the study is to generate biogas from tannery solid waste by mixing with sewage sludge and other wastes.

*Corresponding author E-mail: roufmd@yahoo.com 


\section{Materials and Methods}

\section{Sample Collection}

Different types of tannery waste were collected from 3 types of local tannery at different time. The waste was characterized by analyses, with Standard Methods (APHA, 1992). Substrates were collected at different time and stored at $4{ }^{\circ} \mathrm{C}$, before analysis and other experiments. By examining the present management practices and the characteristics of waste, the fleshing portion of tannery solid waste was chosen as a substrate for biogas generation.

\section{Preparation of substrates}

The limed fleshing used as substrate was grounded to less than $6 \mathrm{~mm}$ diameter using a meat-grinding machine. To this, domestic sewage was added as diluent in different ratio to maintain the fleshing solids in suspension and to achieve the desired level of flowability in the feed mixture. Domestic sewage also act as a source of various microorganisms required for anaerobic digestion. The domestic sewage was collected from different locations of Elephant Road residential area. Cowdung was also used in different proportion as a substrate to maintain the $\mathrm{C} / \mathrm{N}$ ratio. Sewage and Cowdung were also characterized by Standard Methods (APHA, 1992).

\section{Inoculum}

Pre-digested material consisting of all the essential microbes (hydrolyzing, fermentative, acetogenic and methanogenic bacterial consortium) was chosen as an inoculum for the study. The inoculum was synthesized in the laboratory using cow dung, limed fleshing and domestic sewage in equal proportions. After ceasation of gas production, the pre-digested material was tested for its activity with known quantity of sodium acetate as substrate for gas production, and later the digested residue was used as inoculum for the study.

\section{Experimental setup}

In order to examine the appropriate technology for the management of solid waste from tanning industry, anaerobic digestion process has been studied using batch reactors. A simple methanogenic activity test procedure was adopted (Jawed and Tare, 1996). The composition of limed fleshing, domestic sewage, cowdung and inoculum used in the batch experiments have been described in Table I. A known amount of substrate containing a mixture of waste was transferred into $2 \mathrm{~L}$ capacity wide mouth glass bottle. Different quantities of waste materials were mixed and added to the glass bottle to obtain an initial volume of $1 \mathrm{~L}$ in all the reactors, $\mathrm{R} 1$ to $\mathrm{R} 4$ (Table II). The total gas production was measured using a water displacement method at an interval of $24 \mathrm{~h}$. Contents of the glass bottle were mixed manually, after every gas measurement. Daily gas production was recorded. The entire test was conducted at a temperature of $30 \pm 3{ }^{\circ} \mathrm{C}$ for a period of 8 weeks.
In the month of September to November, $1^{\text {st }}$ month was required for the preparation of inoculum. Room temperature, $\mathrm{pH}$ of the effluent were also monitored routinely. From second week volatile solids (VS) reduction and chemical oxygen demand (COD) reduction were monitored. Steady-state condition was identified when the COD value of the effluent and daily biogas production was same for two or three consecutive days.

\section{Process parameters}

Some of the commonly used anaerobic process indicators included $\mathrm{pH}, \mathrm{COD}$ destruction, VS destruction, volatile fatty acid (VFA) concentration, gas production and gas composition. Most of the indicators listed above have been reported as appropriate for evaluating the effect of organic loading rate on the bioconversion of organic substrates and hence, these parameters have been chosen for assessing the decomposition of the substrate investigated in this study.

\section{Analyses}

Carbon and Nitrogen contents of the fleshing, domestic sewage were determined by $\mathrm{C}-\mathrm{H}-\mathrm{N}$ elemental analyzer (Thermo Fischer Scientific, FLASH-2000) with TCD detector. Helium gas was used as carrier gas at $250 \mathrm{kpa}$ and $140 \mathrm{~mL} / \mathrm{m}$, furnace and oven temperature were $900^{\circ} \mathrm{C}$ and $65^{\circ} \mathrm{C}$ respectively. Its moisture and ash contents were estimated by gravimetric methods by drying at $105{ }^{\circ} \mathrm{C}$ and by complete combustion at $800{ }^{\circ} \mathrm{C}$ respectively. The protein content was estimated from the nitrogen content by multiplying with 6.25. Total solids (TS), VS, and VFA were estimated according to the procedures recommended in the standard methods for examination of water and waste water (APHA, 1992). Assay bottles were periodically analyzed for the above-mentioned parameters for a period of 8 weeks. Gas production from the reactors was monitored by means of water displacement method on daily basis. The volume of water displaced from the bottle was equivalent to the volume of gas generated at the temperature and pressure that prevailed during the study period. Gas chromatograph (Thermo Fischer Scientific, Trace GC Ultra) with TCD detector was used to measure methane content and carbon dioxide in the biogas composition. Helium gas was used as carrier gas at $900 \mathrm{kpa}$ and $10.5 \mathrm{~mL} / \mathrm{m}$, oven and detector temperature were $80^{\circ} \mathrm{C}$ and $180^{\circ} \mathrm{C}$ respectively.

\section{Experimental procedures and sampling schedules}

A known quantity of wastes was added in a $2 \mathrm{~L}$ bottle as an initial experiment. On the basis of the result of the experiment four biogas digesters were taken for biogas generation from the substrate by mixing with domestic sewage in different proportions. The digested slurry from initial experiment was used as inoculum for the test reactors. Thus, the test reactors for four different organic loading were constructed. The TS concentration of all reactors was $6 \%$. At the end of every week, one bottle for each VS load was analyzed for various parameters. 
Table I. Characteristics of substrates

\begin{tabular}{lcccc}
\hline Constituents & Limed Fleshing & Domestic Sewage & Cowdung & Inoculum \\
\hline $\mathrm{pH}$ & 10.99 & 6.15 & 6.21 & 6.43 \\
$\mathrm{TS}(\%)$ & 13.38 & 5.00 & 17.00 & 6.00 \\
VS (\%) & 82.57 & 82.00 & 89.00 & 88.60 \\
Oil (\%) & 9.50 & 2.32 & 1.56 & - \\
Protein (\%) & 44.16 & 25.32 & 7.89 & - \\
Moisture Content (\%) & 86.62 & 95 & 83.00 & - \\
COD (mg/L) & - & 1329 & - & - \\
Calorific Value (kcal/kg) & 4323.06 & 4010.04 & 4658.07 & - \\
C/N Ratio & 2.64 & 20 & 24.00 & - \\
\hline
\end{tabular}

Table II. Quantity of lime fleshing, domestic sewage, cowdung and inoculums and the initial VS concentration in the reactors

\begin{tabular}{lcccccc}
\hline Reactors Name & Fleshing (g) & Domestic Sewage (mL) & Cowdung (g) & Inoculum (mL) & Tap water & $\begin{array}{r}\text { Initial VS } \\
\text { Concentration (g/L) }\end{array}$ \\
\hline R1 & 125.00 & 300.00 & 180.00 & 100.00 & 295.00 & 55.33 \\
R2 & 170.00 & 450.00 & 90.00 & 100.00 & 190.00 & 52.45 \\
R3 & 225.00 & 600.00 & 0.00 & 100.00 & 75.00 & 50.80 \\
R4 & 195.00 & 525.00 & 45.00 & 100.00 & 135.00 & 51.56 \\
\hline
\end{tabular}

Table III. Refractory fraction, biodegradable fraction and total VS destruction observed in the reactors

\begin{tabular}{lcccc}
\hline Reactor & $\begin{array}{c}\text { Refractory } \\
\text { fraction of VS }\end{array}$ & $\begin{array}{c}\text { Biodegradable } \\
\text { fraction of VS }\end{array}$ & $\begin{array}{c}\text { \% Biodegradable fraction } \\
\text { of VS (calculated) }\end{array}$ & $\begin{array}{c}\text { \% VS destruction based on } \\
\text { total VS (experimental) }\end{array}$ \\
\hline R1 & 0.484 & 0.516 & 51.6 & 52.06 \\
R2 & 0.499 & 0.501 & 50.1 & 51.94 \\
R3 & 0.623 & 0.377 & 37.7 & 41.37 \\
R4 & 0.562 & 0.438 & 43.8 & 45.04 \\
\hline
\end{tabular}

\section{Results and Discussion}

\section{Characteristics of raw materials}

General characteristics of tannery waste fleshing are given in Table I. The fleshing contains $82.57 \% \mathrm{VS}$ and considerable amount $(9.50 \%$, dry basis). It also contains protein of about $44.16 \%$. The $\mathrm{C} / \mathrm{N}$ ratio of fleshing was 2.64 , which were quite low for optimum biogas generation (Rouf et. al., 2010) and that low $\mathrm{C} / \mathrm{N}$ value increased by mixing with cowdung and domestic sewage. The $\mathrm{pH}$ of the fleshing was extremely high (10.99), which is not favourable to biogas generation. Buffering capacity of cowdung is very good and the domestic sewage would also act as a source of various micro organisms required for anaerobic digestion (Thangamani et. al., 2009).
Biogas generation

Daily gas production

Fig. 1. to Fig. 4 represents the volumes of daily gas accumulation with varying amount of fleshing. Here substrate fleshing, sewage sludge and cowdung were used. In the mixture initially few days were required for biogas generation. After 5 days biogas generation was started properly and then gas generation per day was increased. Then after 45 days food concentration of bacteria was decreased and biogas generation was also decreased significantly. The irregularities of gas production are due to changes of temperature and also for scum formation on the surfaces of the slurry of the biogas digester. So, after breaking of scum by pressure of the biogas inside the digester, sometimes amount of biogas increased abnormally. 
Fig. 1. shows the daily gas generation for reactor R1. It was observed that gas generation started at the very next day of charging the digesters with the slurry. The rate of gas generation gradually increased with increasing the digestion period. The graph also indicates that during the digestion period, most of the day gas production range was in between 200-600 mL. In this reactor, the peak gas production of 1100 $\mathrm{mL}$ was observed on the $34^{\text {th }}$ day. It was observed that gas production rate declined after $54^{\text {th }}$ days.

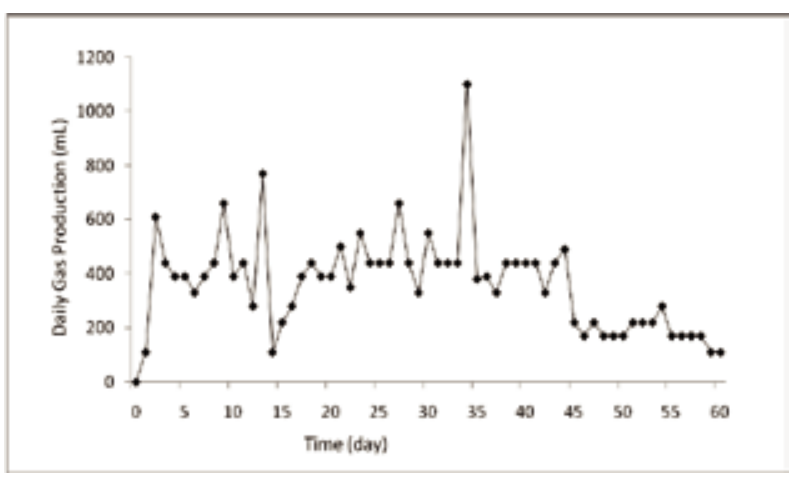

Fig. 1. Daily gas production in the reactor $\mathrm{R} 1$

Reactor R2 (Fig. 2) shows considerable amount of daily gas generation. In this reactor also the generation of gas started from the second day after recharging the reactor with slurry. The peak gas production was observed on the $28^{\text {th }}$ day, the amount was $1100 \mathrm{~mL}$. Here also the gas production range was in between 200-600 $\mathrm{mL}$.

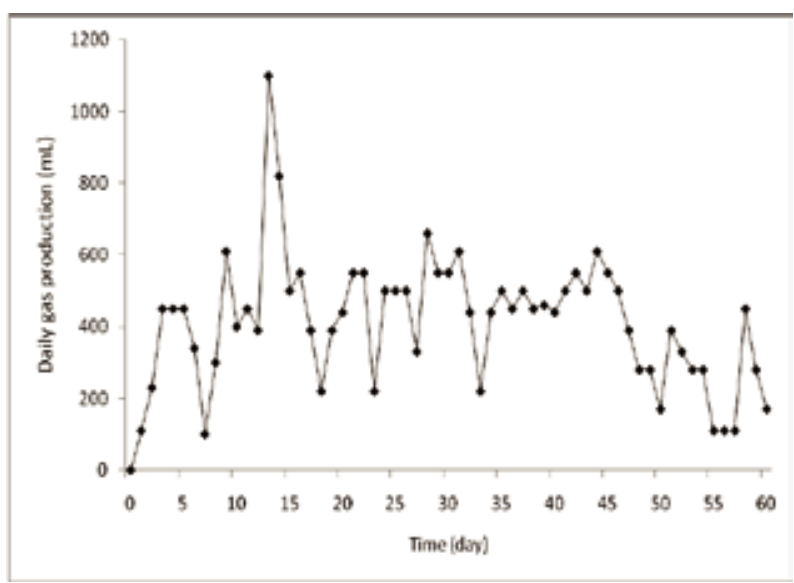

Fig. 2. Daily gas production in the reactor $\mathbf{R 2}$

Fig. 3. represents the daily gas production rate for reactor R3. This shows lower range of daily gas production $(100-300 \mathrm{~mL})$. In this digester, bacteria were taken four days for acclimatization as there was no cowdung in the slurry. The peak gas production was observed $550 \mathrm{~mL}$ at the $23^{\text {rd }}$ day of digestion period.

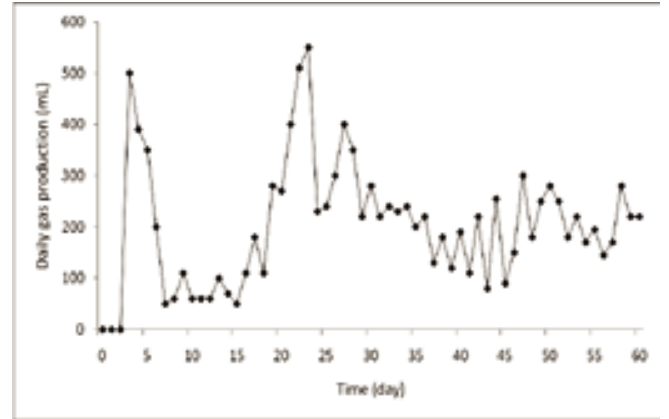

Fig. 3. Daily gas production in the reactor $\mathbf{R 3}$

Fig. 4. shows the daily gas production in the reactor R4. In this reactor also the generation of gas starts at the second day after charging the reactor. The peak gas was $780 \mathrm{~mL}$ which was observed at the $26^{\text {th }}$ day. The gas generation also ceased at the $60^{\text {th }}$ day of digestion period. A gradual shift was observed in the period of peak gas production with increasing VS concentration. One GC chromatogram of a biogas sample has shown in Fig. 5.

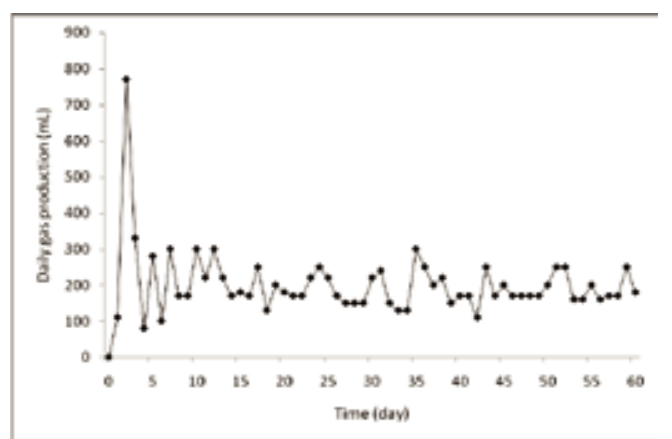

Fig. 4. Daily gas production in the reactor $R 4$

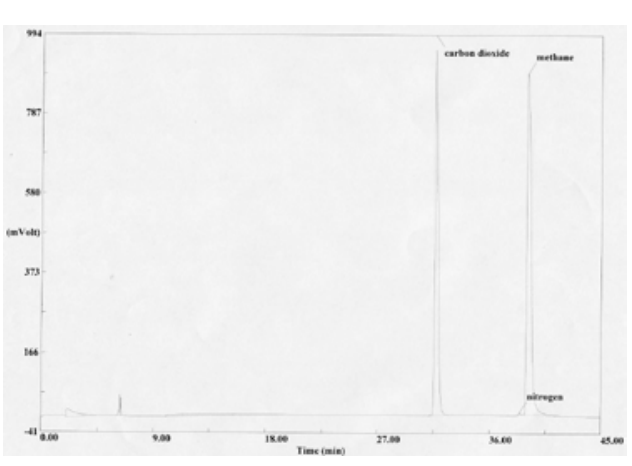

Fig. 5. GC chromatogram of a biogas sample.

\section{Cumulative gas production}

The cumulative gas production from each of the test reactors operating at various organic loading of tannery solid waste, 
domestic sewage and cowdung are shown in Fig. 6. A cumulative gas production from test reactor R1 was 22,200 $\mathrm{mL}$ at the end of the eighth week of the study period. A cumulative gas production from the test reactor R2 was $24,960 \mathrm{~mL}$, while a cumulative gas production of $12,145 \mathrm{~mL}$ was observed in test reactor R3. In the last and fourth reactor $\mathrm{R} 4$ cumulative gas production was observed $14,850 \mathrm{~mL}$. In the four reactors R1, R2, R3 and R4 specific gas production in terms of VS fed were $0.401,0.476,0.239$ and $0.288 \mathrm{~L} / \mathrm{g}$ respectively. Fig. 6 shows that the lag phase prevailed upto 5 to 6 days of digestion period. This was due to microbe limiting at the initial stage of fermentation. The peak generation of gas is delayed as the lag phase was longer. After the lag period, the cumulative volume of gas increased sharply and continued upto 50 to 55 days of fermentation period. After which the rate of gas generation decreased and this declination continues until the gas generation almost ceased. At the end of eighth week gas generation in all the reactors almost ceased.

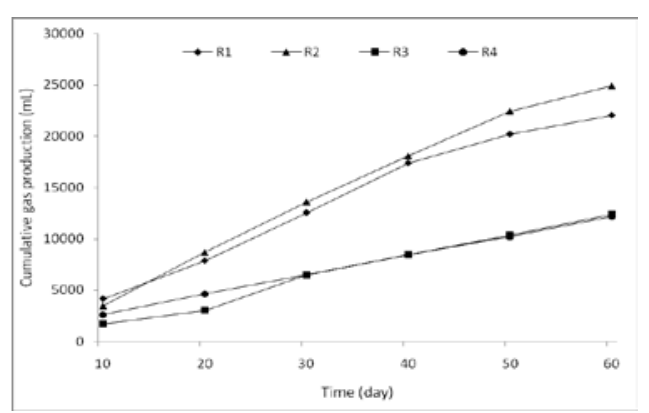

Fig. 6. Cumulative gas production in different reactors ( $R 1, R 2, R 3, R 4)$

\section{$V S$ destruction in batch reactor}

During anaerobic digestion of solid waste, biogas generation is more specifically related to the reduction of biodegradable fraction of VS in the digester. VS reduction in the test reactors was observed in the range of $41.37-52.06 \%$. These values are comparable with the VS reductions reported in the literature for various substrates (Rouf et. al., 2010 and Thangamani et. al., 2009). The percentages of VS of slurry decreased with increasing digestion period. The VS concentration is decreased with time as the part of VS consumed by bacteria for biogas generation (Fig. 7). The percentages of the solids are correlated with the digestion time as the values of $\mathrm{R}^{2}$ are about 0.99 in all cases. The tendencies of concentrations for solids are decreasing with time. But the degree of reduction depends on the initial volatile solids concentration of the slurry (Bosu, 1993). Biogas generation is a biological process and bacteria consume carbon for cell building and energy source extracting from solids which causes solid reduction.

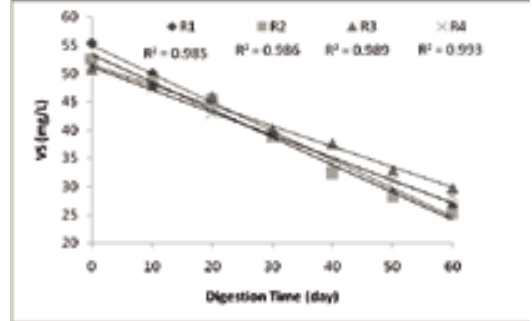

Fig. 7. Volatile Solids with digestion time for different reactors (R1, R2, R3, R4)

\section{COD value reduction}

COD of the slurry was considerably reduced by anaerobic digestion treatment .The reduction of COD value means the reduction of pollution load from any substrate by the treatment process. The COD value curves for four different reactors are shown in Fig. 8. The trend line shows that good correlation exist between digestion time and COD value as the $\mathrm{R}^{2}$ value is above 0.95 for all the reactors.

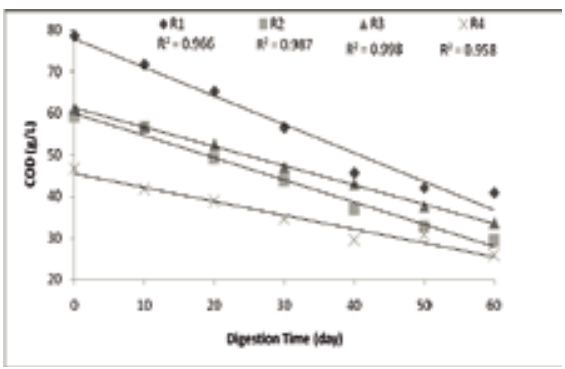

Fig. 8. COD value with digestion time for different reactors $(\mathrm{R} 1, \mathrm{R} 2, \mathrm{R3}, \mathrm{R4})$

For reactors R1, R2, R3 and R4 COD reduction rates were $48.02,50.67,44.80$ and $44.61 \%$ respectively. Maximum COD reduction was achieved from reactor R2 where maximum gas was produced. COD reduction value is comparable with the reference value given by Rahman and Muyeed, 2010.

\section{C/N ratio}

The $\mathrm{C} / \mathrm{N}$ ratio of 2.64 for fleshing materials was very low. Therefore cowdung and domestic sewage were used as co-substrate. The reactors were operated at $\mathrm{C} / \mathrm{N}$ ratio of 18 , 17,15 and 16 respectively which were low from standard value (20 to 30) (Rahman and Muyeed, 2010). But in this range reactors operated without any setback even at lowest $\mathrm{C} / \mathrm{N}$ value $\mathrm{R} 3$ reactor has been given considerable amount of gas. Optimum gas production was obtained at $\mathrm{C} / \mathrm{N}$ ratio 17 of reactor R2.

\section{Biodegradability of feed mixture}

The refractory fraction in the feed mixture is an indicator of the extent of biodegradability of the substrate. It is the portion of initial VS that remains in the digester as solid retention time 
(SRT) approaches infinity (Borja, 1995). The refractory fraction and biodegradability were determined graphically from the intercept of the plot (Fig. 9) drawn between $\left(\mathrm{S}_{\mathrm{i}} / \mathrm{S}_{0}\right)$ and $\left(\mathrm{S}_{0} * \mathrm{t}\right)^{-1}$ where $\mathrm{S}_{\mathrm{i}}=$ substrate concentration $(\mathrm{g} / \mathrm{L}), \mathrm{S}_{0}=$ initial VS concentration $(\mathrm{g} / \mathrm{L})$ and $\mathrm{t}=$ retention time $(\mathrm{d})$. It was in the range of $37.7-51.6 \%$ of the influent volatile solids concentration (Table III). The biodegradability factor indicates the presence of resistant volatile matter in the major portion of volatile solids in the digester. This reasonably conforms to the experimentally determined VS destruction efficiency of $41.37-52.06 \%$ in Table III (Parawira et. al., 2004). Hence, it is essential to monitor the biodegradable fraction of VS in the feed to have better operational control over the process.

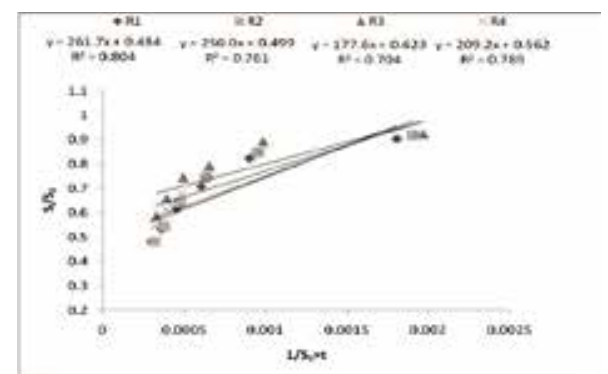

Fig. 9. Refractory fraction of feed mixture for different reactors ( $R 1, R 2, R 3, R 4)$

\section{Conclusion}

The present practices of disposal of tannery waste are not environmentally friendly and cause great concern for Dhaka City. The solid waste fleshing contains about $82 \%$ VS which are amenable to biodegradation. The $\mathrm{C} / \mathrm{N}$ ratio of fleshing is too low and alone is not suitable for biodegradation but mixing with other substrates with fleshing the generation of biogas is very satisfactory. The composition of reactor R2 gives the best performance for specific gas production, reduction of COD and VS reduction. In addition to this the mixing of other substrate improves the environmental condition of the biogas reactor for better anaerobic digestion. The methane content of biogas from the substrate is very satisfactory. The fleshing waste can be used as a complementary substrate part of small scale biogas plants. Use of fleshing will also reduce the cow dung requirement in a biogas plant which is also an important point, because very often cow dung scarcity turns off the biogas plants. The generation of biogas from the substrate is environmentally friendly, hygienic and it will reduce pollution.

\section{Acknowledgement:}

The authors are thankful to Mr. Mohammad Moniruzzaman, Senior Scientific Officer of BCSIR Laboratories Dhaka and the technicians Mr. Nasu Miah and Mr. Md. Abdur Nasir of Institute of Fuel Research and Development, BCSIR, Dhaka.

\section{References}

APHA, AWWA and WEF (1992), Standard Methods for the Examination of Water \& Wastewater $\left(18^{\text {th }} \mathrm{ed}.\right)$, American Public Health Assn, Washington DC.

Borja R (1995), Kinetic evaluation of an anaerobic fluidised-bed reactor treating slaughterhouse wastewater, Bioresource Technol, 52: 163-167.

Bosu SK (1993), Effect of Mechanical mixing and dung concentration on biogas generation, MSc. Eng. Thesis, Department of Civil Eng, Buet, Dhaka, Bangladesh.

Cirne DG, Paloumet X, Björnsson L, Alves MM and Mattiasson B (2007), Anaerobic digestion of lipid-rich waste - effects of lipid concentration, Renewable Energy, 32: 965-975.

Cirne F, Donodo G and Tombetti F (1982), Anaerobic digestion of tannery wastes, Agriculture Wastes, 4(3): 241-243.

Deublein D and Steinhauser A (2008), Biogas from Waste and Renewable Resources, Wiley-VCH, Verlag, Weinheim, Germany.

Jawed M, Tare V. (1996), Methanogenic activity and performance of UASB, DSFF and USFF reactors. Water Sci. Technol, 34: 483-487

Nemec D (2010), Solid waste management options for tannery estate Dhaka, UNIDO technical paper, EE/BGD/09/001 \& $\mathrm{EE} / \mathrm{BGD} / 09 / \mathrm{A} 01$ \& XP/BGD/09/002.

Oliveira S (2004), Formaldehyde degradation in an anaerobic packed-bed bioreactor, Water Res, 38: 1685-1694

Parawira W (2004), Anaerobic batch digestion of solid potato waste alone and in combination with sugar beet leaves, Renew. Energy, 29: 1811-1823.

Rahman MH (1984), A study on tannery waste treatment, M.Sc Eng. Thesis, Dept. of Civil Eng, BUET, Dhaka, Bangladesh.

Rahman MH and Muyeed A (2010), Solid and Hazardous waste management, $1^{\text {st }}$ Ed., ITN-BUET, Dhaka, Bangladesh, p. 179-214.

Rouf MA, Bajpai PK, and Jotshi CK (2010), Optimization of biogas generation from press mud in batch reactor, Bangladesh J. Sci. Ind. Res, 45 (4): 371-376.

Seadi AT, Rutz D, Prassl H, Köttner M, Finsterwalder T, Volk S and Janssen R (2008), Biogas Handbook, University of Southern Denmark, p. 21-23.

Thangamani A, Rajakumar S and Ramanujam RA (2009), Anaerobic co-digestion of hazardous tannery solid waste and primary sludge: biodegradation kinetics and metabolite analysis, Clean Technol. Environ. Policy, 12: $517-524$.

Received: 9 October 2013; Revised: 19 March 2014;

Accepted: 3 June 2014. 